\title{
PARTIDO POLÍTICO, CONSERVADORISMO E DITADURA MILITAR: A ALIANÇA RENOVADORA NACIONAL (ARENA) NA PARAÍBA (1964-1968)
}

\author{
Dmitri da Silva Bichara Sobreira
}

\section{Introdução}

O golpe de Estado deflagrado em março de 1964 não foi obra apenas dos militares, sendo quase um consenso dentro da historiografia que tal movimento teve caráter civil e militar. Autores como Maria Helena Moreira Alves, Marcos Napolitano, Daniel Aarão Reis, Rodrigo Patto Sá Motta, entre outros $^{2}$, têm buscado problematizar a participação de grupos civis, tanto no golpe de 1964 como na ditadura instaurada subsequentemente. A partir de suas obras, é possível afirmar que parte significativa da sociedade civil brasileira participou da empreitada golpista junto aos militares, planejando, financiando ou legitimando o movimento autodenominado "revolucionário" pelos seus adeptos. Uma categoria importante nesse movimento foi a classe política. Por meio de sua participação nas instituições representativas, conspirou-se contra a ordem democrática nacional, legitimou-se a deposição de um presidente democraticamente eleito e institucionalizou-se um Estado de Exceção no Brasil.

Sob a luz dessa perspectiva historiográfica, temos desenvolvido pesquisa acerca da participação de partidos políticos e de seus membros nesse período, tendo como objeto a Aliança Renovadora Nacional (ARENA). Esta foi uma organização partidária criada no ano de 1966 pelo regime autoritário pós-1964, por meio do Ato Institucional $\mathrm{N}^{\circ} 2$ (AI-2), um decreto que extinguiu o sistema pluripartidário criado em 1945 e instaurou um bipartidarismo, composto pela ARENA, encarregada de representar os interesses do governo militar nas instituições democráticas, e pelo Movimento Democrático Brasileiro (MDB), que desempenhou o papel de oposição consentida pelo regime. ${ }^{3}$ Nesse texto, recortaremos o olhar sob nosso objeto de pesquisa nos limites do estado da Paraíba, por meio da análise do Diretório Estadual arenista, e definiremos como marco temporal os anos de 1964 a 1968, enxergando os motivos pelos quais parte da classe política paraibana se associou ao golpe de Estado, articulou-se para formar a secção paraibana da ARENA, bem como o apoio prestado ao governo militar nos quatro primeiros anos do regime.

Nossa premissa para o desenvolvimento desse artigo é que a motivação de setores da classe política paraibana para apoiar o golpe de 1964 e a vincular-se à ARENA foi um majoritário sentimento conservador, contrário às propostas de reformas sociais de base pautadas pelo presidente João Goulart, o Jango ${ }^{4}$. Essa agenda reformista interferiria diretamente na consolidada estrutura social, política e econômica estadual, pautada na concentração fundiária e exclusão das classes subalternas da representação política. Apesar de partilharmos desse raciocínio, reconhecemos que a ARENA, enquanto partido, congregou os mais diversos grupos políticos, numa pluralidade de interesses $e$ ideologias que impossibilita a redução de seus membros a qualquer perfil simplista e generalizante. ${ }^{5}$

\footnotetext{
${ }^{1}$ Doutorando em História pela Universidade Federal de Minas Gerais (UFMG). Bolsista da Coordenação de Aperfeiçoamento de Pessoal de Nível Superior (CAPES). E-mail: dmitri bichara@hotmail.com.

${ }^{2}$ ALVES, Maria Helena Moreira. Estado e oposição no Brasil (1964-1984). Bauru: Edusc, 2004. NAPOLITANO, Marcos. 1964 - história do Regime Militar Brasileiro. São Paulo: Contexto, 2014. REIS, Daniel Aarão. Ditadura e democracia no Brasil. Rio de Janeiro: Jorge Zahar, 2014. MOTTA, Rodrigo Patto Sá. As universidades e o regime militar. Rio de Janeiro: Jorge Zahar, 2014.

${ }^{3}$ Apesar de manter-se dentro dos limites institucionais impostos pelo regime, é possível afirmar que setores dentro do MDB passaram a desempenhar uma oposição mais combativa ao longo da ditadura. KINZO, Maria D'Alva Gil. Oposição e autoritarismo: gênese e trajetória do MDB (1966-1979). São Paulo: Vértice, Ed. dos Tribunais, 1988.

${ }^{4}$ Principal matéria de seu programa de governo, nela constavam: reforma agrária, urbana, bancária, eleitoral, do estatuto do capital estrangeiro e universitária. O debate em torno das propostas reformistas mobilizou grupos progressistas $e$ conservadores em ambos os lados do espectro político.

${ }^{5}$ GRINBERG, Lúcia. Partido político ou bode expiatório: um estudo sobre a Aliança Renovadora Nacional (Arena), 1965 -
} 
Contudo, mesmo dentro dessa diversidade, é possível identificar um comportamento conservador comum, presente em uma cultura política majoritária entre a classe política local.

Dessa forma, o conceito de conservadorismo é capital para o desenvolvimento desse texto, podendo ser definido como um sentimento de aversão a mudanças. Enquanto fenômeno político complexo, difere do tradicionalismo, apresentado como um apego a padrões vegetativos ou modos de vida antigos, considerados oblíquos e universais, algo vinculado a elementos da subconsciência, estando pouco desenvolvido a ponto de se tornar, por si só, um referencial para movimentos políticos. O conservadorismo, por outro lado, é uma estrutura mental objetiva, uma aglomeração de elementos espirituais e intelectuais independentes dos indivíduos que são seus portadores. Um fenômeno que transcende o espaço-tempo, uma configuração estrutural histórica, dinâmica, não estática no tempo, mas condicionada pelas conjunturas nas quais está inserido. Ou seja, enquanto o tradicionalista é quase que exclusivamente reativo, o conservador é coerente, adepto a um movimento que leva em conta as transformações ocorridas de uma época para outra. ${ }^{6}$

Esse conservadorismo engloba características cruciais da chamada "cultura política brasileira". Com a ascensão do paradigma culturalista, o conceito de cultura política tornou-se recorrente nas análises históricas, através de sua interpretação pluralista e não hierarquizante, mesmo que haja a predominância de uma cultura política sobre as demais. Sendo possível defini-la como um "Conjunto de valores, tradições, práticas e representações políticas partilhadas por determinado grupo humano, expressando identidade coletiva e fornecendo leituras comuns do passado, assim como inspiração para projetos políticos direcionados ao futuro". ${ }^{7}$

No nosso caso, a "cultura política brasileira" seria predominante neste espaço nacional. Entre suas características, é possível apontar: a existência de um imaginário político nacional, composto por representações de eventos relevantes do passado e na classificação de personagens históricos como heróis ou vilões; presença de comportamentos e condutas favorecedoras dos laços de parentesco, amizade ou compadrio, que desconsideram normas oficiais em função de projetos políticos por vezes pessoais; tendência à flexibilidade e negociação de conflitos sempre que há membros da elite hegemônica envolvidos (quando as classes populares são parte da disputa, prevalece a utilização de violência contra os desfavorecidos economicamente); pouca participação popular nas instituições públicas e relativa identificação com os partidos políticos (vale ressalvar que esse fator não ocorre por mero desinteresse, mas pela estrutura excludente do sistema político nacional). ${ }^{8}$ Essas características não são exclusivas do Brasil, é a comunhão delas, apreendida junto à formação do Estado Nacional brasileiro, que dá sentido à definição de uma cultura política especificamente brasileira. Tal cultura política não é partilhada por todos os indivíduos dentro desse espaço nacional, marcando especialmente o comportamento daqueles que controlam ou almejam controlar o poder. Ela deve ser interpretada como uma linha mestra que orienta projetos políticos nacionais, influenciando e sendo influenciada por culturas políticas periféricas, presentes no espaço nacional brasileiro.

Em virtude de sua composição ser de ideologias, valores e condutas que privilegiam uma ordem política e econômica historicamente predominante no Brasil, que delimita a atuação das massas populares e privilegia interesses dos chamados "donos do poder" , é possível afirmar que a "cultura política brasileira" tem no conservadorismo sua principal aptidão. No que diz respeito à classe política, o conservadorismo presente na cultura política brasileira pode ser reconhecido em discursos, textos publicados, entrevistas, comportamentos e condutas perante às instituições, ao eleitorado e seus pares. Para a análise de nosso objeto de pesquisa, selecionamos como fontes os principais jornais que circulavam na Paraíba na época de nosso recorte temporal, discursos parlamentares e documentos de cunho organizativo da ARENA. É nessas fontes que buscaremos identificar as representações do conservadorismo, compreendendo o processo de produção, publicação, circulação e leitura desses

1979. Rio de Janeiro: Maud X, 2009.

${ }^{6}$ MANNHEIN, Karl. Sociologia. Tradução: Marialice Mecarini Foracchi. São Paulo: Ática, 1982.

${ }^{7}$ MOTTA, Rodrigo Patto Sá. Ruptura e continuidade na ditadura brasileira: a influência da cultura política. In: ABREU, Luciano Aronne de; MOTTA, Rodrigo Patto Sá. Autoritarismo e cultura política. Porto Alegre: FGV, Edipucrs, 2013, p. 11-12.

${ }^{8}$ MOTTA, Ruptura e continuidade..., p. 15-18.

${ }^{9}$ Termo que dá título à obra de Raymundo Faoro, faz alusão ao patronato brasileiro constituído historicamente em torno das instituições públicas. FAORO, Raymundo. Os donos do poder: formação do patronato político brasileiro. São Paulo: Globo, 2012. 
textos $^{10}$, bem como apreendendo as maneiras pelas quais os indivíduos, ocupando as instituições públicas, retratam e fazer alegações em nome de parte de uma comunidade, como seus representantes democraticamente eleitos. ${ }^{11}$

Assim, a análise do comportamento dos políticos e demais apoiadores civis da ditadura de 1964 ajuda a desconstruir a ideia desse regime como um hiato autoritário no processo histórico brasileiro, pensando o autoritarismo como resultado de um conservadorismo, localizado historicamente à direita ${ }^{12}$ do espectro político e presente também em períodos democráticos do Estado brasileiro. Compreender a natureza desse conservadorismo, suas motivações, interesses e valores não significa compactuar com essa postura, ou relativizar crimes e violências cometidas, que devem ser denunciadas e, porventura, punidas, "Mas, significa inscrever tais ações nos respectivos projetos políticos e situá-los na confluência entre certos contextos e conjunturas". ${ }^{13}$

\section{4: Combate às esquerdas e apoio ao golpe}

Para entender o conservadorismo paraibano à época do golpe e nos anos que se sucedem, é preciso contextualiza-lo no espaço e no tempo. Na década de 1960 a Paraíba ainda era um estado predominantemente rural. Seus setores urbanos, apesar de apresentarem significativo crescimento, tinham relativa importância no cenário político. A indústria paraibana ainda era embrionária, sendo o motor da economia local a agricultura para a exportação e à pecuária extensiva. Comportava alta concentração de terra nas mãos de uma pequena elite agrária, os latifundiários, herdeiros do sistema colonial brasileiro, fator que resultava em um histórico poderio político para esse grupo. Todavia, o final da década de 1950 e início dos anos 1960 representaram o ápice do período democrático inaugurado em 1945: havia significativa amplitude do sufrágio no país, regularidade dos pleitos eleitorais e a possibilidade de representação política-institucional das camadas populares e de seus interesses de classe. A chegada de Jango à presidência - político de tradições trabalhistas, responsável por transformar o Partido Trabalhista Brasileiro (PTB) de varguista em aliado do Partido Comunista Brasileiro (PCB) -, potencializou a viabilidade de ação de grupos organizados à esquerda, ligando o sinal de alerta na classe conservadora brasileira.

$\mathrm{Na}$ Paraíba, as esquerdas atuavam em frentes sindicais e de classe, como a Comissão Intersindical (COSINTRA), o núcleo local do Comando Geral dos Trabalhadores (CGT) e a Associação Paraibana de Imprensa (API); no movimento estudantil, secundarista e universitário, mobilizado em torno de entidades estudantis ou em iniciativas como a Campanha de Educação Popular (CEPLAR), projeto inspirado no método Paulo Freire de educação das camadas populares; e na cultura, destacando-se a atuação do teatrólogo Paulo Pontes, produtor de peças, musicais e folhetos que difundiam valores de esquerda. ${ }^{14}$ Contudo, o grupo organizado que mais destacava-se em meio às manifestações de esquerda era o das ligas camponesas, um movimento social composto por trabalhadores do campo dispostos a defender os interesses e prestar assistência ao proletariado rural. Originário no rompimento do camponês com o controle dos latifundiários, baluartes do conservadorismo local, que, por meio da propriedade rural, sua representação nas instituições públicas e controle da força policial, exploravam ao máximo o trabalho do campesinato e mantinham o camponês sob seu domínio político por meio

\footnotetext{
${ }^{10}$ CHARTIER, Roger. À beira da falésia: a história entre certezas e inquietude. Tradução: Patrícia Chittoni Ramos. Porto Alegre: UFRGS, 2002.

${ }^{11}$ PITKIN, Hanna. O conceito de representação. In: Cardoso Fernando Henrique; MARTINS, Carlos Estevam. Política e sociedade. São Paulo: Cia. Ed. Nacional, 1979, p. 8-22.

${ }^{12}$ A díade direita-esquerda, apesar de ter sua viabilidade questionada por grupos de intelectuais vinculados a paradigmas historiográficos ascendentes após o ano de 1989, apresenta-se útil para nossa abordagem histórica haja vista que nos referimos a atuação de partidos políticos na conjuntura da Guerra Fria. Dessa forma, apesar de reconhecermos a pluralidade de vertentes existente em cada lado espectro político, é possível definirmos essa díade atribuindo à esquerda valores como a coletividade e a igualdade, enquanto à direita são atribuídos valores como individualidade e mérito. BOBBIO, Norberto. Direita e Esquerda: razões e significados de uma distinção política. Tradução: Marco Aurélio Nogueira. São Paulo: Editora da UNESP, 1995.

${ }^{13}$ MOTTA, Rodrigo Patto Sá. História, memória e disputas pela representação do passado recente. Patrimônio e memória. São Paulo: Unesp, v. 9, n.1, 2012, p. 174.

${ }^{14}$ NUNES, Paulo Giovani Antonino. Golpe civil-militar na Paraíba: repressão e legitimação. In: NUNES, Paulo Giovani A.; SILVA, Rodrigo Freire de Carvalho e; DANTAS, Eder. Golpe civil-militar e ditadura na Paraíba: história, memória e construção da cidadania. João Pessoa: UFPB, 2014, p. 82.
} 
do voto de "cabresto". ${ }^{15}$

Essas elites conservadoras paraibanas estabeleceram poucas organizações de classe, destacando-se a Associação dos Proprietários da Paraíba (APRA), a Liga dos Proprietários (LILA) e a Federação das Indústrias da Paraíba. ${ }^{16}$ Não obstante, o conservadorismo local exercia sua representação política diretamente pela via política institucional, através dos partidos políticos, os quais conservavam um viés oligarquizado de períodos anteriores da República brasileira. Entre 1945 e 1964, os dois principais partidos no estado eram a União Democrática Nacional (UDN) e o Partido Social Democrático (PSD), que disputavam as principais eleições subsequentemente ao longo desse período, sendo a principal forma de representação política das tradicionais oligarquias locais. Essas organizações eram orbitadas por legendas menores, mas de perfil similar, com as quais se coligavam na formação de chapas eleitorais. Partidos como o PTB, o Partido Liberal (PL), Partido Republicano (PR), Partido Democrata Cristão (PDC), entre outros, formalizavam alianças com a UDN ou o PSD em função de interesses das oligarquias que chefiavam essas agremiações.

A tendência oligarquizadora é um fenômeno presente nos partidos políticos, como mostram as principais tipologias e modelos evolutivos formulados sobre essas organizações. ${ }^{17} \mathrm{Na}$ Paraíba, essa tendência vinculava-se diretamente à posse da terra. $\mathrm{O}$ controle do latifúndio era feito através de práticas da cultura política brasileira, como o clientelismo, mandonismo e patrimonialismo, hereditariedade ou invasão de terras, casamentos entre membros da mesma família, ou de famílias aliadas, e violência contra quem se opusesse ao controle do mandatário rural. ${ }^{18}$ No período de 1945 a 1964, outras estratégias para a conservação do controle do latifúndio, envolvendo os partidos, foram adotadas. A "paz agrária": pacto de não agressão política estabelecido entre os membros do Grupo da Várzea, que controlava as usinas e plantações de cana-de-açúcar na várzea do Rio Paraíba ${ }^{19}$; e a "pacificação política": aliança entre partidos historicamente adversários, no intuito de evitar o desgaste de um embate eleitoral direto. Além desses, com a radicalização das esquerdas às vésperas do golpe de 1964, o conservadorismo foi reforçado através do discurso político destinado à desconstrução dos grupos de esquerda, sendo dois episódios marcantes em sua difusão: a "tragédia de Marî" e a "invasão da Faculdade de Direito".

"Tragédia de Marí" foi como ficou conhecido o conflito ocorrido no mês de janeiro de 1964 na cidade de Marí, protagonizado por camponeses e indivíduos ligados aos latifundiários da zona da várzea do Rio Paraíba. Trabalhadores rurais contratados por um proprietário rural encontravam-se iniciando o preparo da terra, quando um grupo composto por policiais militares à paisana $e$ funcionários da Usina São João, pertencente ao Grupo Ribeiro Coutinho, tradicional família vinculada ao Grupo da Várzea, chegou ao local e iniciou o conflito, acreditando que os camponeses estavam invadindo aquela propriedade. O desfecho do fato foi uma série de mortes, em sua maioria de homens pertencentes ao Grupo da Várzea. A tragédia foi veiculada pelos principais jornais do estado como "Chacina de Marí", os quais culparam as ligas camponesas pelo ocorrido.

Diante de protestos de parte da sociedade, o governador do estado, Pedro Gondim (PDC), abriu inquérito investigativo e montou forte esquema de repressão aos camponeses, enviando numeroso contingente policial comandado pelo cel. Luís de Barros, conhecido pelo perfil agressivo aos movimentos sociais. $\mathrm{O}$ apoio de parte da classe política dava a dimensão do conservadorismo paraibano. O deputado estadual Otávio Mariz Maia (UDN) enfatizou seu apoio à medida, interpretando a repressão aos camponeses como uma ação voltada para a ordem e a paz social.

Vemos sangue a derramar-se na Paraíba. Esta é a responsabilidade que pesa sobre o homem público que pede que a paz reine em nosso Estado. Tenho sentido a maior sensibilidade e o maior interesse por parte do Chefe do Executivo em adotar medidas acauteladoras, medidas saneadoras, medidas corretoras para pôr fim a esta crise [...] Apoio o governo Pedro Gondim tentando ajudar ao povo paraibano a restabelecer a ordem pública e a paz social. Este é o meu dever. E quanto mais apertarem o cerco

\footnotetext{
${ }^{15}$ BENEVIDES, César. Camponeses em marcha. Rio de Janeiro: Paz e Terra, 1985.

${ }^{16}$ NUNES. Golpe civil..., p. 88.

${ }^{17}$ PANEBIANCO, Angelo. Modelos de partidos. São Paulo: Martins Fontes, 2005.

${ }^{18}$ BENEVIDES, Camponeses em..., p. 80.

${ }^{19}$ BENEVIDES, Camponeses em..., p. 33.
} 
contra eles mais perto de sua pessoa me encontrarão. ${ }^{20}$

O deputado estadual Batista Brandão (PDC) alegou que não era intensão dos latifundiários usar da violência contra o camponês: "(...) os proprietários não desejam ensopar o solo paraibano com o sangue dos camponeses. O que querem é trabalhar e produzir". ${ }^{21}$ Por sua vez, o senador João Agripino (UDN) alegou que as ações repressivas de Gondim decorriamm da defesa do direito à propriedade privada:

(...) como a lei assegura o direito de propriedade, o proprietário entende que é dever da autoridade estadual assegurar esse direito através da ação da polícia. (...) $\mathrm{O}$ governador Pedro Gondim em todos esses episódios tem feito sentir a presença da ação policial na manutenção da ordem e preservação dos direitos assegurados. ${ }^{22}$

A "invasão da Faculdade de Direito" foi outro evento que acirrou os ânimos entre as esquerdas e a classe conservadora paraibana. Ocorrida em março de 1964, na ocasião da visita do governador da Guanabara, Carlos Lacerda (UDN) à Paraíba. Lacerda, um dos mais ativos críticos do governo Jango e de suas reformas de base, foi impedido de discursar na Faculdade de Direito por estudantes que ocuparam o prédio. Grupos simpatizantes a Lacerda, liderados pelos deputados estaduais Joacil de Brito Pereira (UDN) e Marcos Odilon Ribeiro Coutinho (UDN), mobilizaram-se para expulsar os estudantes do prédio da Faculdade de Direito. Para evitar o conflito, soldados do $15^{\circ}$ Regimento de Infantaria $\left(15^{\circ} \mathrm{RI}\right)$ e policiais militares interviram no local, retirando e levando presos os estudantes.

A crítica aos estudantes que ocuparam a Faculdade de Direito ganhou contornos mais severos na Assembleia Legislativa. Para Ribeiro Coutinho: “(...) não foram os estudantes da Faculdade de Direito, mas uma pequena e isolada minoria em conluio com os profissionais da baderna, os responsáveis pelos lamentáveis acontecimentos da terça feira". ${ }^{23}$ Assim como Brito Pereira, que ao explicar sua intervenção Faculdade de Direito, condenou a atitude dos estudantes:

(...) lembrando que o Senador Juscelino Kubitscheck, o Governador Miguel Arraes e outros políticos já estiveram em João Pessoa e os estudantes não se empiriquetaram para reprimi-los. Só o governador Lacerda, símbolo de coragem e bravura na luta contra o comunismo no Brasil, merecera tratamento tão descortês. ${ }^{24}$

Brito Pereira alegou, ainda, que sua luta não era contra os estudantes, mas contra quem discordasse de sua ideologia liberal: "É a luta de um liberal contra libericidas (...) se há estudantes que estão comprometidos com os libericidas, então, sim, a minha luta é contra eles". ${ }^{25}$ Esses acontecimentos serviram de termômetro para medir a disputa política no estado e como estimuladores das forças conservadoras para apoiar o golpe.

Nesses dois episódios é possível perceber os principais aspectos do comportamento conservador da classe política estadual: o combate aos grupos populares e de esquerda pela defesa de uma ordem social, da propriedade privada e das liberdades individuais. Quando se fala em ordem social, o discurso reproduzido criminaliza qualquer ação das camadas populares em busca de direitos $e$ representação política; tem-se na propriedade privada algo historicamente estabelecido $e$ inalienável; $e$ a respeito das liberdades individuais, busca-se deslegitimar qualquer ação de coletividades organizadas que almejem expressar ideias e representar os interesses das classes subalternas. Todos esses aspectos são reforçados por um vocabulário oriundo de um imaginário anticomunista, intrínseco ao projeto político conservador e valoroso na dialética entre as classes dominantes e populares, utilizando-se de valores como a ordem e a paz social, supostamente combatida pelos comunistas. ${ }^{26}$

Quando desencadeado o golpe, em março de 1964, parte da classe política paraibana louvou a

\footnotetext{
${ }^{20}$ A União, 21 de janeiro de 1964, p. 3.

${ }^{21}$ A União, 22 de janeiro de 1964, p. 8.

${ }^{22}$ A União, 28 de janeiro de 1964, p. 8.

${ }^{23}$ A União, 5 de março de 1964, p. 8.

${ }^{24}$ A União, 5 de março de 1964, p. 8.

${ }^{25}$ A União, 11 de março de 1964, p. 8.

${ }^{26}$ MOTTA, Rodrigo Patto Sá. Em guarda contra o perigo vermelho: o anticomunismo no Brasil (1917-1964). São Paulo: Perspectiva, 2002.
} 
ação dos militares. No dia posterior à deposição de Jango, o governador Pedro Gondim emitiu nota transmitida via rádio para todo o estado, na qual afirmava seu apoio às Forças Armadas:

Os últimos acontecimentos, verificados no Estado da Guanabara, envolvendo marinheiros e fuzileiros navais, denunciaram, porém, inequívoca e grave ruptura na disciplina em destacado setor das classes armadas, com desprezo às linhas hierárquicas e completa alienação às prerrogativas da autoridade, sustentáculo autêntico da segurança nacional. O movimento que eclodiu nestas últimas horas em Minas Gerais, com repercussão em outros Estados, não é mais nem menos do que a projeção de acontecimentos anteriores, numa tentativa de recolocar o país no suporte de sua estrutura legal, propiciando clima de tranquilidade - indispensável ao processo desenvolvimentista que vivemos. ${ }^{27}$

Junto ao governador, o deputado federal Vital do Rêgo (UDN) reiterava a nota publicada, afirmando:

A Paraíba, sempre na vanguarda dos grandes acontecimentos nacionais, está pronta, sob o comando resoluto e forte do governador Pedro Gondim, a defender as instituições e nunca de braços cruzados entregá-las à sanha dos agitadores, ao clima de anarquia, a perpetuação do poder nas mãos dos maus, que só queriam, personalisticamente, o egoísmo, a vaidade, o ódio $e$ o desrespeito à família, à pátria $e$ à paz social. ${ }^{28}$

Enquanto presidente da Assembleia Legislativa, o deputado estadual Clóvis Bezerra (UDN) manifestou, por meio de telegrama veiculado na imprensa, o apoio daquela instituição ao golpe de 1964. Nele, Bezerra afirma:

Pode o povo paraibano ficar certo de que os seus representantes [deputados estaduais], sem dissensões partidárias e ponto a sua confiança em Deus, supremo dirigente dos destinos dos povos, apoiam como deve e como podem os pronunciamentos dos comandos e das chefias, das autoridades e dos cidadãos que se identificam na defesa da Constituição da República, contra a subversão e a anarquia. Até que se defina a situação nacional, a Assembleia Legislativa ficará em Sessão Permanente. ${ }^{29}$

Parte significativa da classe política paraibana não só legitimou o golpe, como iniciou um movimento para eliminar seus adversários políticos, considerando necessário o expurgo daqueles que buscavam a transformação da estrutura social oligárquica, taxados de "comunistas". A Assembleia Legislativa, já em abril, antecipou-se às determinações estabelecidas pelo governo federal no Ato Institucional $\mathrm{N}^{\circ} 1$ (AI-1) e procedeu ela mesma a cassação dos políticos vinculados aos movimentos sociais. Através de um Projeto de Resolução elaborado pelo deputado Joacil de Brito Pereira, e referendado pelos seus pares, a Assembleia cassou o mandato dos deputados estaduais Assis Lemos e Langstein de Almeida, e dos suplentes Figueiredo Agra e Agassiz de Almeida, todos do Partido Socialista Brasileiro (PSB). Para Brito Pereira, esses, por terem identificação com os movimentos sociais, eram "Porta-vozes da revolução abortada pela vigilância de nossas Forças Armadas" $e$ estavam "(...) a serviço de ideologia estrangeira". ${ }^{30}$

O golpe de 1964 foi o ápice de um movimento político conservador, que visava barrar uma pauta progressista que ganhava espaço na democracia brasileira, uma agenda política que almejava romper privilégios e um histórico controle das elites econômicas e sociais dentro das instituições públicas. Para preservar a ordem social que lhe contemplava, bem como suas práticas e ideologias políticas, setores da classe política paraibana logo trataram de associarem-se ao movimento encabeçado pelos militares, congratulando-se e legitimando, dentro das próprias instituições democráticas, um movimento que rompia com o ritual da democracia nacional.

\footnotetext{
${ }^{27}$ GONDIM apud NUNES, Golpe civil..., p. 91.

${ }^{28}$ A União, 2 de abril de 1964, p. 8.

${ }^{29}$ A União, 2 de abril de 1964, p. 8.

${ }^{30}$ A União, 8 de abril de 1964, p. 8.
} 


\section{5-1966: Formação da ARENA e reorganização oligárquica}

Em 1965, passado um ano do golpe de Estado e a onda de violência e expurgos contra os considerados "subversivos" pelo novo regime político que se instaurava, o governo militar adotava a postura de diálogo com as instituições de representação política, no intuito de criar uma aparência de legitimidade para a ditadura que se instaurava no país. Nesse sentido, apesar de cancelar as eleições presidenciais, por meio da prorrogação do mandato do general Castelo Branco, primeiro militar a assumir a presidência, o regime manteve as eleições estaduais daquele ano, que ocorreriam em onze estados da federação. ${ }^{31} \mathrm{~A}$ derrota de candidatos governistas em dois dos principais estados do país (Rio de Janeiro e Minas Gerais) gerou uma preocupação do regime acerca da possibilidade de as esquerdas encampassem novamente as instituições representativas.

Para barrar uma possível reorganização dos grupos políticos vinculados ao governo Jango, o regime decretou o Ato Institucional $\mathrm{N}^{\circ} 2$ (AI-2). Elaborado por lideranças civis e militares, esse decreto foi baixado pelo presidente no final de outubro daquele ano. O AI-2 aumentava o poder do presidente através da transferência de responsabilidades do Legislativo e Judiciário para o Executivo. Nele, encontravam-se medidas exclusivas para o Congresso, como a redução de maioria simples para a aprovação de ementa constitucional pelo Executivo e transferia para o Executivo competências sobre questões orçamentárias das Forças Armadas. O AI-2 foi responsável por extinguir o antigo sistema pluripartidário, considerado um entrave na relação entre governo e Legislativo, sendo as diretrizes para a formulação do bipartidarismo traçadas pelo Ato Complementar $\mathrm{N}^{\circ} 4$ (AC-4). Neles estavam previstas a criação de até três organizações provisórias com atribuições de partidos políticos, impedindo a reorganização dos partidos recém-extintos. Entre 1965 e 1966 foram formados a ARENA, legenda que congregaria os apoiadores do regime distribuídos no antigo sistema partidário, e o MDB, partido no qual se acomodariam os opositores do regime sobreviventes aos expurgos de 1964.

Na Paraíba, o AI-2 foi recebido com aceitação e cautela pela classe política. Enquanto o governador Pedro Gondim enviara telegrama ao presidente da República prestando-lhe apoio pela medida ${ }^{32}$, a Assembleia Legislativa decreta sessão permanente até tomar maior conhecimento sobre aquele decreto. As poucas palavras proferidas pelos parlamentares demonstram um sentimento de incerteza que pairava sobre a classe política local ${ }^{33}$. Os partidos políticos extintos pelo AI- 2 foram por vinte anos os instrumentos de acesso ao poder da classe política, o mapa partidário estabelecido em 1945 definia as possibilidades de alianças e coligações políticas entre as oligarquias, bem como, foi através deles que a classe política estabeleceu vínculos com o eleitorado.

$\mathrm{Na}$ ótica da imprensa local, a criação de novos partidos seria um meio de superar as práticas políticas favorecedoras de condutas pouco democráticas (aparelhamento do Estado, controle do eleitorado e outras fraudes eleitorais), renovação de ideias e ideologias políticas e possibilitaria a renovação dos quadros da política local. ${ }^{34}$ Contudo, quando houve a formação dos dois partidos na Paraíba, a esperada renovação da política não ocorreu. Ao analisarmos a criação do Diretório Estadual da ARENA, identificamos que João Agripino, governador eleito no pleito estadual de 1965, foi o encarregado de organizar o Diretório Estadual do partido. Essa missão foi delegada pelo presidente Castelo Branco, sendo parte de uma estratégia do regime em indicar os governadores estaduais para liderar a formação da ARENA nos estados, deixando o partido no controle da máquina estadual. A influência de Agripino nesse processo fez com que a criação do Diretório Estadual da ARENA-PB se confundisse com a formação de seu governo. Os membros da coligação UDN/PDC/PL, pela qual Agripino foi candidato ao governo, encabeçaram a formação do partido, seguidos por dissidentes da coligação $\mathrm{PSD} / \mathrm{PTB} / \mathrm{PR}$, base para a estruturação do MDB paraibano. A possibilidade de união de grupos historicamente rivais eleitorais em um único partido só foi possível através da sublegenda, um mecanismo previsto no bipartidarismo que possibilitava um partido se subdividir em até três sublegendas em embates eleitorais majoritários e de criar facções independentes dentro do partido,

\footnotetext{
${ }^{31}$ Ocorreram pleitos diretos nos estados de Alagoas, Goiás, Guanabara, Maranhão, Mato Grosso, Minas Gerais, Pará, Paraíba, Paraná e Rio Grande do Norte.

${ }^{32}$ O Norte, 28 de outubro de 1965, p. 8.

${ }^{33}$ O Norte, 29 de outubro de 1965, p. 8.

${ }^{34}$ SOUTO. O Norte, 30 de outubro de 1965, p. 2.
} 
sendo primordial para a viabilidade do bipartidarismo no âmbito local. Dessa forma, a ARENA-PB dividiu-se em ARENA-1, formada pelos aliados do governador, e ARENA-2, composta pelos dissidentes da coligação derrotada na eleição de 1965.

Pelo interior do estado, foi alto o número de adesões de grupos políticos à ARENA, inclusive de opositores aos correligionários de João Agripino, gerando manifestações de revolta entre seus aliados. Intencionado a contornar a situação, o governador reuniu seus correligionários em um jantar no Palácio da Redenção, sede do poder Executivo estadual, para explanar seus objetivos através do novo partido político. Respaldado pelas premissas do governo federal, Agripino explicou em discurso que sua perspectiva era a de congregar as principais lideranças políticas paraibanas, unindo todos aqueles que desejassem compor com aquilo que chamavam de "governo revolucionário". Tentando convencer seus aliados da importância de aceitar rivais históricos no partido, Agripino encerrou seu discurso relatando conversa com Castelo Branco, na qual o general perguntou se haveria restrições em aceitar adversários políticos na ARENA:

Quero, pois, falar, precisamente, aos que vieram compor conosco, com o partido do Governo Federal, a ARENA do Estado da Paraíba, para lhes dizer que quando fomos consultados pelo Presidente da República sobre se tínhamos restrições ou dificuldades a aceitar adversários nesse novo partido, respondendo que nenhuma dificuldade tínhamos e nenhuma objeção ao ingresso de qualquer dos adversários de última luta. A nossa afirmativa foi da mais absoluta sinceridade. ${ }^{35}$

A concretização da formação da ARENA-PB ocorreu em março de 1966, em reunião na antiga sede da UDN local. Nela foram eleitos os membros da Comissão Executiva Estadual, Conselho Fiscal e seus respectivos suplentes. Os membros do Diretório Regional que assumiram cargos no partido eram indivíduos dotados de longeva vida pública e ocupantes de cargos eletivos e/ou profissões de respaldo na sociedade. ${ }^{36}$ Além de sua estrutura interna, o Diretório Estadual da ARENA-PB lançou carta na qual se posicionava em relação ao futuro presidente da República e quais seriam os interesses dessa secção regional junto ao novo governo. O documento foi enviado ao presidente nacional da ARENA, senador gaúcho Daniel Krieger, e divulgado pelo jornal A União, periódico oficial do Estado. Em editorial, o jornal, que prestou cobertura durante todo o processo de formação do partido, avaliou a carta:

Contendo as teses nacionalistas - de autêntico interesse do País - pode ser apontado, por igual, como uma súmula das mais justas e prementes reivindicações do Nordeste, incluída, obviamente, a Paraíba. O oportuno e conciso documento revela clarividente espírito público, acuidade administrativa e, sobretudo, perfeita identificação com os grandes problemas da atualidade brasileira e da região nordestina. ${ }^{37}$

No documento, foram indicados pela ARENA-PB para a sucessão presidencial os generais Adhemar de Queiroz, Costa e Silva, Cordeiro de Farias, Ney Braga e o próprio senador Daniel Krieger, os dois últimos nomes indicações do próprio João Agripino e os demais escolhidos pela Comissão Executiva. ${ }^{38}$ A maioria dos indicados eram figuras do alto escalão das Forçar Armadas, mostrando o interesse dos arenistas paraibanos com a manutenção dos militares no controle do país.

Como indicações de pautas para o regime, a ARENA-PB dividiu o documento em duas vertentes, a primeira, voltada para o desenvolvimento econômico e social nacional, era composta pelos itens: a) evolução da economia nacional visando atingir taxa de crescimento superior à $6 \%$ ao ano; b) consideração especial aos problemas regionais de desenvolvimento de modo a eliminar progressivamente as diferenças existentes dentro do país; c) combate à inflação, sem restrição ao desenvolvimento das atividades produtivas, que compreenda a aplicação selecionada e ordenada dos recursos governamentais, a eliminação progressiva dos déficits das empresas públicas e a sua gradual submissão a critérios privados de administração, a melhoria do sistema geral de transporte, o estímulo à elevação da produtividade em setores essenciais, à arrecadação rigorosa dos tributos realmente

\footnotetext{
${ }^{35}$ A União, 20 de março de 1966, p. 4.

${ }^{36}$ Ata de criação da ARENA-PB. ARENA op. a 1966.01.20.

${ }^{37}$ Editorial. A União, 29 de abril de 1966, p. 3.

${ }^{38}$ A União, 26 de abril de 1966, p. 3.
} 
devidos, a administração de crédito por faixas de prioridades e equilíbrio orçamentário sem sacrifício aos investimentos básicos ao desenvolvimento; d) prioridade absoluta à redução dos problemas de reforma agrária, respeitando-se as peculiaridades de cada área ou zona e facilitando o acesso à terra; e) execução de programas realísticos e efetivos de reforma agrária; f) fortalecimento da empresa nacional, e preservação em poder dos empresários brasileiros dos centros de decisão da economia nacional; g) manutenção da política do monopólio estatal do petróleo, fortalecendo-se a Petrobrás; h) exploração dos recursos naturais do país, preferencialmente através de empresas com maioria de capital nacional; i) formulação e execução de política educacional pela qual, ao mesmo tempo, se possa eliminar o analfabetismo e preparar a população para tarefas comuns ao processo de desenvolvimento econômico, através de ensino médio e superior adaptado à realidade $e$ às necessidades brasileiras; j) formulação e execução de uma política habitacional compatível aos níveis de renda da população, respeitada as condições próprias de cada região do Brasil; k) adoção de uma política creditícia que estimule o desenvolvimento de produção da agricultura, da pecuária e da indústria, desencorajando a intermediação desnecessária; 1) eliminação da pesada carga tributária, direta ou indireta, que recai sobre as classes de renda baixa; $\mathrm{m}$ ) unificação e melhora da previdência social, de modo a evitar o desperdício de recursos e a proporcionar a assistência efetiva aos contribuintes dos atuais instintos de previdência; n) elaboração de política administrativa em que se elimine os privilégios $e$ se assegurem estímulos adequados $e$ inarredáveis aos servidores públicos capazes e efetivamente vinculados à necessária melhoria da eficiência da máquina governamental. ${ }^{39}$

A segunda parte do documento destinava-se especialmente aos interesses da Paraíba e do Nordeste: a) considerar a Sudene como órgão efetivo de planejamento, coordenação, encaminhamento, e controle do investimento do governo federal na região; b) caracterização dos programas e projetos aprovados pela Sudene como de absoluta prioridade, inclusive para o fim de concessão oportuna, dos recursos federais necessários à sua execução, cabendo à Sudene à proposição dos respectivos calendários de desembolso; c) manutenção do sistema de incentivos à iniciativa privada através da Sudene e órgãos regionais de fomento; d) manutenção da Sudene e do BNB fora de injunções políticas; e) entrosamento efetivo entre os órgãos federais do nordeste, inclusive a Sudene, e os governos estaduais para a formulação, execução e controle dos programas relativos com desenvolvimento regional; f) manutenção dos incentivos compensatórios das atuais desvantagens locacionais do nordeste, inclusive no que respeita às tarifas do serviços públicos. ${ }^{40}$

Ao analisarmos as diretrizes do documento, percebe-se o interesse dos membros da ARENA-PB no fortalecimento da classe empresarial, por meio de benefícios fiscais, investimentos e incentivos governamentais no setor privado e prioridade da empresa nacional na execução de projetos; fortalecimento dos interesses privados nas instâncias de poder, a exemplo da Superintendência do Desenvolvimento do Nordeste (Sudene); bem como a manutenção da ordem por meio de projetos de assistência social e reformas de base (reforma agrária) numa perspectiva que não alterasse a estrutura oligárquica nacional. Vale ressaltar ainda a tendência à manutenção da estrutura política oligarquizada no estado, apenas adaptada ao novo e artificial sistema bipartidário. Como a maioria dos políticos identificavam-se à ditadura pós-1964 em função do conservadorismo intrínseco a classe, o próprio regime tratou de estabelecer formas de agregar os grupos opositores sem causar qualquer trauma, através de artifícios estabelecidos pelo novo regimento partidário, ou pela atuação das lideranças regionais vinculadas à ditadura.

\section{6-1968: Institucionalização do regime autoritário}

Enquanto partido situacionista, a secção paraibana da ARENA contribuiu nesses quatro primeiros anos na institucionalização da ditadura e defesa dos seus interesses por meio de seus representantes eleitos. O diálogo estabelecido entre o regime e as instituições democráticas é parte do esforço governamental de transparecer para as nações liberais ocidentais que no Brasil ainda se operava uma democracia nos moldes das que existiam naqueles países. Por vezes, essa característica do regime autoritário brasileiro é utilizada por setores sociais para relativizar o autoritarismo dos militares. Haviam

\footnotetext{
${ }^{39}$ A União, 26 de abril de 1966, p. 3.

${ }^{40}$ A União, 26 de abril de 1966, p. 3.
} 
no Brasil eleições regulares, funcionamento do Congresso Nacional e existência de partidos políticos inclusive de oposição -, porém, as eleições ocorriam de forma direta apenas para parte dos cargos públicos (presidente, governador e prefeito das capitais e cidades consideradas zonas de segurança nacional eram eleitos de forma indireta), o Congresso atuou mutilado por cassações, sem plenos poderes para legislar e sempre que se tornava um entrave para os interesses governamentais era fechado pelo regime, e os partidos existiam dentro de um limitado e artificial sistema bipartidário imposto pela ditadura. Além disso, eram operadas outras demonstrações de violência que moldaram aquele regime como um Estado de exceção: censura, prisões arbitrárias, tortura e assassinatos políticos, comuns desde o imediato pós-golpe.

Nesse sentido, a classe política foi fundamental para a institucionalização do regime nos âmbitos federal e estadual. Para compreender o papel da ARENA-PB nesse processo e a forma como o conservadorismo influenciou o apoio dos arenistas à ditadura, selecionamos os episódios da cassação do prefeito de João Pessoa e a indicação de um interventor para o cargo, em 1966; a adaptação da Constituição estadual à nova Carta federal, em 1967; e as manifestações sociais ocorridas em 1968 que culminaram com a decretação do Ato Institucional No 5 (AI-5).

Em 1966 o governo militar continuava sua "limpeza" nas instituições públicas através de expurgos e cassações de mandatos de políticos, como foi o caso do prefeito de João Pessoa, Domingos Mendonça Netto. Filiado ao extinto PSB e eleito prefeito em 1963 com o apoio do então PSD, Mendonça Netto não tinha vinculação com o grupo político de João Agripino. Após o golpe de 1964, o prefeito da capital passou a ser vigiado pelo governo militar, contra ele foi aberto um Inquérito Policial Militar (IPM) para investigar sua administração na prefeitura de João Pessoa. Ainda em 1964 esse processo foi arquivado pela Assembleia Legislativa, sendo reaberto um ano depois e encaminhado para o Ministério da Justiça. Em abril de 1966, o presidente Castelo Branco baixa um decreto baseado no AI2, cassando seu mandato. ${ }^{41}$ No seu lugar, assume Damásio Franca, vice-prefeito eleito junto a Mendonça Netto, mas que se encontrava afastado do cargo após assumir a secretaria de Viação $e$ Obras Públicas do governo estadual. Em seu discurso de posse, Franca reverenciou o governo militar e revelou o apoio prometido por Agripino à sua administração: "Contarei, de certo, com o apoio do Exmo. Sr. Governador João Agripino Filho. E com o apoio igualmente das Forças Armadas, sediadas na Paraíba, guardiãs da democracia, da honestidade e do trabalho a serviço do povo brasileiro". ${ }^{4}$

Não foram encontrados registros de declarações de João Agripino na ocasião da cassação de Mendonça Netto e na posse de Franca, porém, o A União, enquanto periódico oficial do Estado, justifica a medida tomada pelo regime:

Não se tripudia sobre o caráter político do Prefeito da capital, no momento em que um Ato imperativo e indispensável da Revolução Democrática, empreendida contra corruptos e subversivos, tira-lhe todos os poderes do cargo. Deplora-se que não tenha querido servir ao povo da principal cidade paraibana, que de presente ofereceu-lhe para - talvez única - oportunidade na vida. Deplora-se o efeito negativo que um procedimento incorreto, incompatível com a alta dignidade do cargo, traz de certo modo para as gerações moças engajadas na vida política e administrativa do Estado. Deplora-se o prejuízo incalculável que a cidade sofreu em mais de dois correspondentes a sua presença no posto-chave de que acaba de ser apeado. ${ }^{43}$

Por meio do discurso de combate a corrupção, feita sem apreciação independente do sistema judiciário, o regime realizou expurgos em diversos setores da administração pública, em processos nos quais os acusados não tinham o direito de apresentar sua defesa. Para os militares, a corrupção era avaliada como um problema de ordem moral, atrelada à demagogia e desonestidade, um vício potencializado ao longo da democracia instaurada em 1945. Até a produção desse texto, não há fontes disponíveis para avaliação do mérito da cassação de Mendonça Netto, contudo, percebe-se uma conveniência ocasional em sua cassação: necessidade de colocar alguém aliado ao governador na prefeitura da capital, haja vista que já vigorava no Brasil o Ato Institucional $\mathrm{N}^{\circ} 3$ (AI-3), decreto que institucionalizou as eleições indiretas para presidente e governador, bem como indicava que o último

\footnotetext{
${ }^{41}$ O Norte, 21 de abril de 1966, p. 8.

42 O Norte, 21 de abril de 1966, p. 8.

${ }^{43}$ Editorial. A União, 21 de abril de 1966, p. 3.
} 
seria responsável por indicar o prefeito da capital. Dessa forma, é possível perceber que o discurso anticorrupção do regime servia aos interesses do comando da ARENA-PB em manter o controle das instituições públicas estaduais por oligarquias partidárias ao regime, garantindo concomitantemente que essas se manteriam atreladas ideologicamente à ditadura.

Em 1967, o governo militar, preocupado com os formalismos jurídicos, julga necessário elaborar uma nova Constituição incorporando todos os decretos autoritários, Atos Institucionais e Atos Complementares baixados pelo regime. Por meio de um novo Ato Institucional, de número quatro, o governo convoca o Congresso para a realização de uma Assembleia Constituinte. Os debates envolvendo a nova constituição tiveram pontos de discordância entre o governo e parte da bancada da ARENA, especialmente no que diz respeito às garantias de liberdades individuais, eleições indiretas $e$ equilíbrio entre os três poderes. ${ }^{44}$ Apesar de aprovada a nova Constituição pelo Congresso, a Constituinte de 1967 revelou que não havia uma coesão uníssona entre governo e seu partido, haja vista que as medidas apresentadas pelos militares minavam as possibilidades de atuação da classe política.

Apesar dos impasses de interesse entre a ARENA e o governo federal, o partido articulou-se nos estados para adaptar as Cartas Constitucionais estaduais à nova Constituição Federal. Na Paraíba, João Agripino convocou comissão de juristas para elaborar o anteprojeto constitucional a ser debatido pela Assembleia Legislativa. $\mathrm{O}$ anteprojeto apresentado ao Legislativo estadual teve alguns pontos questionados pela oposição, como a criação do Tribunal de Contas do Estado, a eleição indireta para vice-governador $e$ as alterações nas atribuições da Assembleia Legislativa. A oposição denunciava o caráter político prevalecente nessas medidas, que aumentavam o poder do Executivo estadual sobre o parlamento e na gestão dos municípios. ${ }^{45} \mathrm{O}$ anteprojeto alterava ainda as regras para cassação de parlamentares: se, após o envio do requerimento de licença para a cassação, a Assembleia não deliberar o pedido, esse será incluído automaticamente na ordem do dia por quinze sessões ordinárias consecutivas, sendo a licença automaticamente concedida caso não seja feita votação nesse prazo. ${ }^{46} \mathrm{~A}$ mudança visava dinamizar o processo de expurgos dos mandatos parlamentares.

Em plenário, a bancada do MBD, minoria na Assembleia, utilizou-se de todos os procedimentos possíveis para retardar a votação do projeto constitucional no intuito de aprofundar o debate sobre as emendas da nova Carta. Na primeira sessão, destinada para votação das emendas, ocorrida em maio, o deputado Ronaldo Cunha Lima (MDB) apresentou requerimento pedindo destaque para todas as ementas apresentadas, numa contraproposta ao requerimento de Silvio Porto (ARENA), líder da bancada de seu partido, no qual solicitava votação global das emendas constitucionais. Tentando impedir a votação do requerimento arenista, a bancada do MDB ocupou a tribuna da Assembleia por seis horas consecutivas, gastando o tempo de 20 minutos de que tinha direito cada parlamentar, criticando o projeto constitucional e o requerimento de Porto. Após mais de dez horas de sessão e esgotada a estratégia do $\mathrm{MDB}$, o requerimento apresentado por Porto foi votado e aprovado em plenário. $^{47}$

No segundo dia de discussão, antevendo novos protestos da oposição, Silvio Porto apresentou pedido de questão de ordem aprovado pela presidência da Assembleia impedindo que o MDB levasse o projeto constitucional para debate. Já nessa sessão, o projeto foi votado e aprovado pelos deputados em tempo recorde de menos de 48 horas. A bancada da ARENA na Assembleia, liderada por Porto, atuou como um "rolo compressor" - termo utilizado pela imprensa da época, pela sua postura coesa e conivente com os interesses do governo estadual e do regime autoritário. ${ }^{48}$ Acerca do processo de adaptação da constituição na Paraíba é preciso levar em consideração que, à época, a ARENA-PB convivia com constantes insatisfações de facções com o governo estadual, contudo, determinadas pautas, em especial aquelas que envolviam os interesses diretos do regime, aguçavam o governismo de seus membros.

A nova Constituição foi oficializada em sessão solene na Assembleia, boicotada pela bancada do

\footnotetext{
${ }^{44}$ GRINBERG, Partido..., p. 106-111.

${ }^{45}$ O Norte, 31 de março de 1967, p. 3.

${ }^{46}$ Correio da Paraíba, 31 de abril de 1967, p. 12.

${ }^{47}$ A União, 9 de maio de 1967, p. 8.

${ }^{48}$ Correio da Paraíba, 10 de maio de 1967, p. 8.
} 
$\mathrm{MDB}$, mas que contava com a presença da bancada governista e demais lideranças políticas e militares do estado. O presidente da Assembleia, Clóvis Bezerra (ARENA), em seu discurso, ressaltou o pioneirismo da Paraíba nesse novo debate constitucional, o estado foi um dos primeiros a adaptarem sua Constituição. Membro mais atuante do partido nesse aspecto, Sílvio Porto, ignorando a forma unilateral - de cima para baixo - a qual a adaptação constitucional desencadeou-se, afirmou em discurso na sessão solene que a nova Constituição é um “(...) estatuto sensível, cheio de calor humano, que reflete as tendências, o comportamento e as reinvindicações do povo" ${ }^{49}$. Por fim, a nova Constituição estadual recebeu a assinatura de todos os parlamentares presentes, uma forma de atestar sua participação e colaboração na formulação desse documento.

O ano de 1968 é um marco temporal importante para a ditadura em função das manifestações sociais ocorridas contra o regime. Um setor social que se destacou na oposição ao governo federal foi o movimento estudantil, que mesmo com a repressão sofrida após o golpe de 1964, manteve-se atuante por meio de manifestações públicas, motivadas pelo combate à ditadura e pelo descaso do governo com as necessidades cotidianas da classe. No mês de março, numa dessas campanhas, os estudantes cariocas protestavam contra o corte de subsídios operado pelo regime e contra a administração do restaurante estudantil Calabouço por uma empresa privada. Durante uma dramatização protagonizada por estudantes no local, a Polícia Militar (PM) reprimiu os presentes com tiros. Na confusão, o secundarista Edson Luís de Lima Souto, de 16 anos, foi atingido e morreu na hora. $\mathrm{O}$ assassinato do estudante gerou forte comoção na sociedade brasileira, tornando-se emblemático para as oposições ao regime. Nas ruas, sacadas dos prédios, na Assembleia e em Igrejas, a comunidade expressou das mais diversas maneiras sua revolta contra o crime.

$\mathrm{Na}$ Paraíba os estudantes secundaristas e universitários se mobilizaram em solidariedade aos estudantes cariocas. Nos dias que se seguiram à tragédia do Calabouço, ocorreram manifestações estudantis contra a violência operada por órgãos do governo. Temendo que a radicalização das manifestações do Rio de Janeiro se refletisse na Paraíba, o secretário de Segurança Pública do Estado, brigadeiro Firmino Ayres de Araújo, acatando ordens do governo federal, publicou nota comunicando a proibição de quaisquer concentrações públicas, passeatas ou comícios no estado. ${ }^{50}$ Como estratégia para burlar a proibição, os estudantes passaram a organizar comícios relâmpagos em João Pessoa e Campina Grande. Essas manifestações resultaram em novos confrontos com a Polícia, sendo o mais grave desses embates ocorrido na capital. Nele, após a celebração de missa em homenagem ao sétimo dia da morte de Edson Luís, os estudantes seguiram em passeata pelas ruas do centro da cidade quando um contingente de policiais desembarcou de caminhões portando baionetas e bombas de gás para dispersar a manifestação, desencadeando reação estudantil, que vaiaram e atiraram pedras nos policiais. Oito manifestantes foram presos, e, além deles, um oficial da reserva do Exército e um comerciante foram detidos por protestarem contra a atitude da PM. Nesse mesmo dia ocorreu um novo confronto entre a policiais e estudantes secundarista, no qual três estudantes foram baleados. ${ }^{51}$

A violência praticada pela PM somou-se como mais um motivo de revolta para a classe estudantil. Sob o slogan de "o luto e a luta", foram proferidos discursos no Restaurante Universitário (RU), localizado no parque Solón de Lucena, no centro de João Pessoa. O local foi interditado pela PM e o Centro dos Estudantes Universitários (CEU), foi ocupado por policiais, a ação repreensiva resultou em novos conflitos com os estudantes. Acuados, os estudantes retiraram-se para o Palácio da Redenção, localizado há poucos quarteirões de distância do RU, o qual tentaram ocupa-lo, e, sem sucesso, passaram a depredá-lo. Os policiais interviram com tiros, chegando a atingir pessoas que se encontravam próximas ao confronto. O centro da cidade ficou sitiado pelas tropas da PM, instaladas em prédios das universidades da região. ${ }^{52}$

Quase uma semana após o início dos confrontos entre estudantes e a PM, motivado pela repercussão negativa da repressão policial, o governador do Estado, responsável pelo controle da PM, pronunciou-se para a sociedade, através de uma rádio local, explicando os acontecimentos. Em sua fala, transcrita pelo jornal $O$ Norte, o governador lamentou o assassinato do secundarista na

\footnotetext{
${ }^{49}$ Correio da Paraíba, 13 de maio de 1967, p. 7.

${ }^{50}$ Correio da Paraíba, 3 de abril de 1968, p. 8.

${ }^{51}$ CITTADINO, Monique. Poder local e ditadura militar: o governo João Agripino - Paraíba (1965-1971). São Paulo: EDUSC, 2006, p. 326-327.

${ }^{52}$ CITTADINO, Poder local..., p. 329.
} 
Guanabara e afirmou ser legítimo o protesto estudantil pela morte do companheiro. Porém, reprovou a conduta dos estudantes locais ao criticarem as Forças Armadas, o presidente da República e o governador do Estado. Narrando os acontecimentos, Agripino relativizou a violenta intervenção policial e, fazendo menção a possíveis "infiltrados", culpou os estudantes pela confusão causada nessas manifestações.

Se o governo do Estado corre riscos quando dá instruções para que a polícia reprima atentados à ordem, o risco é que a polícia possa se exceder, os estudantes correm o mesmo risco de que no seu seito se abriguem outros que não tenham nenhum interesse na reinvindicação estudantil, mas tem outros interesses inconfessáveis que os estudantes nem sempre podem perceber. Não sei se vocês me entendem na hora em que depredam residências, invadem pensões, se atiram contra policiais, na hora em que recrutam barras de ferro para enfrentar a polícia através de violências. Não sei se me entendem que esta é a maior violência do que todas as outras e que destas violências quem pode aproveitar não é o estudante, mas outros que estão com uma preocupação diferente: querem levar o país à desordem, à anarquia, à desmoralização dos poderes constituídos. ${ }^{53}$

No final da transcrição do discurso, o jornal destaca um telegrama enviado pela Federação das Indústrias da Paraíba, solidarizando-se com o posicionamento do governador, interprete do "pensamento unânime das classes produtoras" ${ }^{54} \mathrm{~A}$ fala de Agripino segue a mesma lógica do discurso conservador do período anterior ao golpe de 1964, que condenava a conduta dos movimentos populares e de esquerda, atrelando-os à "baderna" e à "desordem". Como representante eleito, falava em nome das elites econômicas locais, que viam na ditadura um governo que privilegiava seus valores e interesses, como o anticomunismo e a propriedade privada.

$\mathrm{Na}$ Assembleia Legislativa, oposição e parte da situação reforçaram a crítica ao governo do Estado pela repressão ao movimento estudantil. ${ }^{55}$ Por outro lado, as lideranças da ARENA defenderam o posicionamento do governador, culpando os estudantes pela confusão instaurada pela truculência policial. Em nome da bancada de seu partido, Silvio Porto (ARENA) lembrou em discurso a desobediência dos estudantes à recomendação do governo federal:

Daí vieram os choques. A presença do público gerou uma reação dos estudantes. O que aconteceu em seguida foi a soma de vários componentes. A reação gerando reação, violência gerando violência. Os ânimos exaltados são incontroláveis. O mundo passa por uma fase de transição. O que ocorre atualmente em todos os países é uma luta de gerações. As novas gerações lutando para modificar as estruturas arcaicas criadas pelas gerações mais velhas. A juventude brasileira não pode fugir a essa contingencia. Não nego que tenha havido excessos dos policiais paraibanos. Nego que se queira imputar esses somente aos policiais da Paraíba. E que se queira dar a um homem público [João Agripino] a responsabilidade de um fenômeno que é universal. $^{56}$

Os acontecimentos da Guanabara foram temas de debate também no Congresso Nacional. O paraibano Ernani Sátiro (ARENA), líder da bancada de seu partido, lamentou os acontecimentos $e$ encaminhou voto de pesar pelo falecimento do estudante secundarista. Porém, Sátiro repudiou aqueles considerados "subversivos", que estariam infiltrados nas manifestações estudantis, tendenciosos a comprometer a ordem do país.

Mas é preciso não confundir as situações. Todos nós fomos estudantes, todos nós temos ou tivemos filhos, parentes, estudantes, mas é necessário não confundir a situação dos estudantes que estudam, dos estudantes quando lutam pelos seus direitos, pelas suas prerrogativas, com a agitação que procura perturbar o País, estabelecer o crime e a desordem. Contra isso o Governo tomará as providências compatíveis com os instrumentos constitucionais de que dispõem. A ordem pública

\footnotetext{
${ }^{53}$ O Norte, 9 de abril de 1968, p. 8.

${ }^{54}$ O Norte, 9 de abril de 1968, p. 8.

${ }^{55}$ A União, 4 de abril de 1968, p. 8.

${ }^{56}$ A União, 9 de abril de 1968, p. 3.
} 
será mantida sem violência, a ordem pública será mantida sem violarmos a Constituição mas esses agitadores que se infiltram entre os estudantes, que envolvem os estudantes, esses serão punidos de acordo com a lei, de acordo com a Justiça. [...] Nós não temos interesse em jogar mais lenha nesta fogueira, mas nossa posição é firme em defesa do regime, em defesa da Constituição, contra o crime e contra a desordem. ${ }^{57}$

É notório o esforço de setores da ARENA-PB na desconstrução dos movimentos sociais organizados e na defesa do regime militar. Enquanto representantes eleitos, os membros do partido governista atuavam nas instituições públicas legitimando as arbitrariedades cometidas pelo regime, por meio de discursos e condutas que privilegiava os interesses da classe conservadora local em conluio ao projeto autoritário implementado pelo regime.

Contudo, a relação entre o regime e as instituições liberais sofre uma nova ruptura no momento em que o governo baixa AI-5, um decreto autoritário, que, entre outras determinações: fechou por tempo indeterminado as casas legislativa, dando aos militares o direito de cassar mandatos eletivos; dava poderes ao regime de demitir, remover ou aposentar compulsoriamente funcionários públicos $e$ membros do judiciário; dava ao Executivo poder de decretar Estado de Sítio, independente dos impedimentos fixados na Constituição; suspendia a garantia de habeas corpus em casos de crimes contra a Segurança Nacional; dava direito ao Executivo de legislar por decreto, entre outras atribuições. ${ }^{58} \mathrm{O}$ marco para essa ruptura entre governo $e$ instituições foi a tentativa do regime em cassar o deputado federal Márcio Moreira Alves, do MDB da Guanabara. Em discurso no Congresso, Alves protesta contra a invasão de tropas do Exército à Universidade de Brasília, e, recomenda à população para boicotar os desfiles militares de sete de setembro, e pede às moças para que não se relacionem com militares envolvidos na repressão. ${ }^{59}$

Suas palavras afetaram a honra das instituições militares e essas pediram para que o governo cassasse o mandato de Alves, o qual encaminhou ao Congresso documento atendendo a solicitação. No entanto, a bancada da ARENA não acatou de forma unânime o requerimento do governo, pois haviam setores no partido que julgavam aquela atitude como um atentado à inviolabilidade do mandato parlamentar. A votação do pedido de licença para cassar Alves ocorreu em dezembro de 1968, sendo seu resultado: 216 deputados votaram contra a licença,141votarama favor da licença $e$ 12 votaram em branco, sendo 94 os arenistas contrários à concessão da licença. ${ }^{60} \mathrm{Na}$ bancada da ARENA paraibana, dos sete deputados, cinco votaram favorável ao regime e dois votaram contra, Pedro Gondim e Wilson Braga. Vale ressaltar que os dois arenistas contrários aos interesses do regime encontravam-se afastados do núcleo dirigente do partido, fator que dava mais liberdade para a tomada de posições contrárias ao regime.

Após a decretação do AI-5, poucas foram as manifestações de arenistas paraibanos. Apenas João Agripino, em nome do governo do Estado, posicionou-se oficialmente, demonstrando solidariedade ao presidente Costa e Silva. ${ }^{61}$ Apesar do episódio Márcio Moreira Alves e a decretação do AI-5 ser considerada uma crise na relação da ARENA com Executivo, em relação à maioria dos políticos paraibanos do partido não há adversidades evidentes com o governo federal.

$\mathrm{O}$ que se percebe ao longo de todo o período analisado nesse tópico é uma subserviência $e$ cooperação dos arenistas em relação ao Estado autoritário. Nas instituições públicas, a maioria dos parlamentares do partido mantiveram-se coerentes com as orientações do governo federal. O governo estadual sempre se mostrou solícito para reprimir qualquer manifestação contra o governo ditatorial. $\mathrm{E}$ mesmo quando as atitudes do governador tinham repercussão negativa perante a opinião pública, havia o consentimento da maioria da bancada arenista na Assembleia, seja poupando-o de críticas ou defendendo-o de acusações de deputados de oposição.

\section{Considerações finais}

\footnotetext{
${ }^{57}$ Diário do Congresso Nacional, 3 de abril de 1968, p. 1173-1174

${ }^{58}$ ALVES, Estado..., p. 161.

${ }^{59}$ ALVES, Estado..., p. 157-160.

${ }^{60}$ GRINBERG, Partido..., p. $121-125$.

${ }^{61}$ O Norte, 17 de dezembro de 1968, p. 1.
} 
Por meio do discurso e da conduta de parte da classe política paraibana que filiou-se à ARENA $e$ nela permaneceu em seus primeiros anos, foi possível diagnosticar um comportamento conservador fundado em aspectos intrínsecos aos "donos do poder" na Paraíba: comportamento favorável a grupos econômicos interessados na valorização da propriedade privada como algo alienável, na preservação do poder político das tradicionais oligarquias estaduais, na segregação social e exploração da classe trabalhadora. Esse comportamento conservador impulsionou grupos políticos a deslegitimarem, dentro das instituições de representação política, as manifestações de movimentos sociais populares e de esquerda por reformas estruturais no país, bem como a apoiar um golpe de Estado e a legitimar um governo adepto de ações arbitrárias e autoritárias contra os considerados subversivos. Esses mesmos setores da classe política se reorganizaram no partido fundado pela ditadura para lhe dar apoio nas instituições representativas. Dentro desse partido, a classe conservadora ao mesmo tempo que legitimava ações arbitrárias, como cassações de mandatos, repressão a grupos sociais organizados $e$ institucionalização do autoritarismo, utilizava dos mecanismos do regime para tirar vantagens para fortalecimento de suas oligarquias políticas e para seus respectivos projetos pessoais.

Apoiar o governo instaurado através do golpe de 1964 serviu para o fortalecimento das práticas conservadoras da "cultura política brasileira". Após a retirada de Jango da presidência, a classe política de direita utilizou das instituições públicas para reprimir adversários políticos; quando da formação da ARENA, percebe-se a imediata oligarquização do partido através da atuação de João Agripino, o qual conseguiu mediar conflitos e possibilitar a união de históricos adversários políticos na mesma instituição partidária; a ARENA, enquanto organização política, serviu como representante dos interesses da elite econômica, setor importante do conservadorismo, junto aos novos governantes do país; bem como os Atos Institucionais baixados pelo regime, ao mesmo tempo que servia como forma de repressão dos militares sobre a sociedade civil e as instituições democráticas, foram utilizados pelos arenistas para aumentar seu poder dentro das instituições pública e introduzir aliados políticos nos mais importantes cargos públicos do Estado.

Por fim, é importante ressaltar que o estudo dos políticos conservadores paraibanos na ditadura não se esgota no recorte temporal proposto para este texto. Tanto no âmbito estadual, como no nacional, esses indivíduos agiram em outros momentos da ditadura: seja no auge da repressão, ou em período de distensão do regime. Desde já, afirmamos a necessidade de promover pesquisas que contemplem esses períodos, bem como que façam uso de análises comparativas entre os conservadores de distintos estados da federação, ou entre os conservadores do Brasil e de outras nações latino-americanas que passaram por experiências autoritárias semelhantes e contemporâneas ao caso brasileiro. Vale destacar, ainda, que o conservadorismo brasileiro tem reaparecido e ganhado espaço nos ambientes públicos de debate, especialmente em momentos de crise de nossa frágil democracia. Repensar sua atuação em passados remotos e recentes pode contribuir na compreensão dos fenômenos do conservadorismo contemporâneo. E compreender é o primeiro passo para combater. 


\section{RESUMO}

O presente artigo tem como objetivo analisar o conservadorismo partilhado por setores da classe política paraibana na ocasião do golpe de Estado deflagrado no Brasil em 1964 e nos quatro primeiros anos da ditadura instaurada subsequentemente. Através da análise da Aliança Renovadora Nacional (ARENA), partido político criado pelo regime autoritário com a finalidade de representar seus interesses nas instituições democráticas que se mantinham em funcionamento, nos dedicamos a compreender as motivações que levaram parte da classe política paraibana a associar-se ao golpe de 1964, a filiar-se à ARENA, bem como o apoio prestado na legitimação do regime. A premissa com a qual trabalhamos é que o que levou parte da classe política local a adotar postura favorável ao golpe e a ditadura foi um majoritário sentimento conservador, contrário às propostas de reforma de base do governo João Goulart e a atuação dos grupos e organizações populares e de esquerda no estado. Nesse sentido, um valoroso conceito que utilizaremos em nossa análise é o de cultura política, diagnosticando a existência de uma "cultura política brasileira", dotada de valores, tradições, imaginários, práticas $e$ representações políticas, as quais fundamentam uma conduta conservadora nesse estado. Os elementos conservadores presentes na "cultura política brasileira" foram identificados em discursos, entrevistas e textos publicado pelo partido e seus membros, presentes em fontes históricas como os jornais que circulavam na época e em documentos referentes a organização interna da ARENA.

Palavras-chave: ARENA; Partido político; Conservadorismo.

\section{ABSTRACT}

The overall purpose of this paper is to analyze the conservatism shared by sectors of political class in Brazilian state of Paraíba by the time of the coup d'etat launched in the country in 1964 and in the first four years of the dictatorship subsequently established. Through the analysis of the Aliança Renovadora Nacional (National Renewal Alliance - ARENA in the Portuguese acronym), a political party created by the authoritarian regime to represent its interests in the democratic institutions that remained in operation, this research's effort is in order to understand the motivations that led part of the political class in Paraiba to associate to the coup of 1964, to join the ARENA, as well as the support provided in the legitimation of the regime. The working premise is that a major conservative feeling, contrary to the proposals of basic reform of João Goulart's government and to the action of the groups and popular organizations from left in the State, is what drove part of the local political class to adopt a stance favorable to the coup and the dictatorship. In this sense, a valuable concept in this analysis is the one of political culture, diagnosing the existence of a Brazilian one, endowed with values, traditions, imaginaries, practices and political representations, which base a conservative behavior in that State. The conservative elements in the "Brazilian political culture" could be identified in speeches, interviews and texts published by the party and its members, present in historical sources like the newspapers that circulated contemporaneously and in documents referring to the internal organization of ARENA.

Keywords: ARENA; Political party; Conservatism

Artigo recebido em 31 jul. 2018.

Aprovado em 13 set. 2018. 